\title{
プラステシンを用いた鋼の熱間孔型圧延の 変形過程に関する研究
}

\author{
五 弓勇雄**, 斎藤好弘*** \\ The Investigation of the Deformation Processes of Hot Caliber \\ Rolling of Steel Using Plasticine as a Model Material \\ Isao Gokyu and Yoshihiro SAITo
}

Synopsis:

Three typical passes i. e. square-oval pass, square-dia. pass and box-pass for caliber rolling were designed which had concave-, convex- and normal shapes of projected contact surface respectively. Model billetsbuilt up of alternate layers of gray and white plasticine were prepared and part-rolled between smooth plaster cast rolls using $\mathrm{CaCO}_{3}$ powder as lubricant whose condition was well known to give a good simulation of hot rolling of steel and the deformation patterns were analyzed so as to reveal the deformation process of caliber rolling.

The results were as follows:

(1) The deformations of equidistant lines perpendicular to the direction of rolling on the billet surface are characterized by the shape of contact surface, i. e. in square-oval pass of concave-shaped contact surface the lines bend backward. In square-dia. pass of convex-shaped contact surface, however, bending is forward instead of backward. There is no bending in box-pass of normal contact surface.

(2) The elastic wedge in the material at the entry side shortens its length or eventually vanishes if its location is near the middle of billet for square-oval pass or near the edge for square dia. pass. This effect means that there is such interaction between the parts of long contact-arc and short one that the deformation of the former facilitates the deformation of the latter. In other words, the deformation of the former is restrained by the latter.

(3) In all cases, adhesion of material to the rolls occurs over a wide area of contact surface except narrow zones near entry and exit.

(4) The neutral point for caliber rolling can be determined from normal strain distribution in the direction of rolling because at the neutral point the velocities of roll-surface and the material are equal, thus normal strains along the arc of contact and along the center line of material must be equal. This point approximately coincides with the point of maximum bending of line perpendicular to the direction of rolling in the plane normal to the roll axis. The neutral lines in both caliber rollings except box-pass are slightly bent backward.

(5) The normal strain in the direction of spreading along the horizontal center line of the cross-section of rolled billet is relatively small and uniform in square-dia. pass. In square-oval pass, however, it is extremely large near the edge and small in the middle.

(Received 10 Sept. 1966)

\section{1. 緒言}

压延の際の金属の变形はロールと材料の接触面に作用 する摩擦力，楔形の弾塑性境界およびロール間隙の幾何 学的交非対称性のために相当複雑なものである.しかし この変形二のものは死延後の材料断面形状や疪あるいは 機械的性質に影響寸るばかりでなく, 压延の力学上密接 な関係を有子るのて，今までにかなり多くの研究がなさ れてきた。しかしそ机らの研究はほとんど板材あるい: 角材の平王延に関子るものてあり，孔型压延に関するも の泣稀でる。として熱間压延の際の材料の流れは，最
初は材料に貫入したネジや材料側面に罢書いた網目の变 形過程を調べる方法1) 3)がとられ，年の後プラステシン に上る模型実䮖も行なわれ4）最近ソ連で表面に正確に絧 目を買書いた金属板を溶接によつて結合し压延する方 法5）が行なわれている。冷間压延に関しても同様の研 究5)6711のにか!，鋼の場合Fry 試薬なよ゙によるエツチ

* 昭和41年 9 月 10 日受付 本論文は本会編集委員会よりの依頼論次でありま 声。

** 東京大学工学部 工缚

*** 東京大学工学部 
ング法7〜9)，鏡面仕上げした側面の凹凸を光をあてて観 察寸る方法10111)，硬度分布法打上び再結晶法 ${ }^{12}$ に上り弾 性契の形状が求められている。

孔型圧延の際の変形に関しては, 粗材の断面や孔型の 形状が多種多様であるうえ，变形が 3 次元的になつてさ らに複雑になるので研究の数も少なく，貫入しだジの 变形を調べたもの1のほかに最近プラステシンを使つて 各種の孔型生延に対する圧延後の材料断面内の雪子状態 を調べた研究13があるだけである。したがつて孔型圧延 の变形過程に関する研究は著者の知るかぎり全くない， そこで著者は孔型在延における変形過程を調べるためプ ラステシンを用い，著者が接触面の形状によつて 3 種に 分類した孔型压延の中からそれぞれ典型的な代表例とし て, ボックス压延, 角 $\rightarrow$ オーバル压延㧍よび角 $\rightarrow$ ダイヤ 圧延を選び，それぞれの変形過程を調べ比較した。

\section{2. 実 験 方 法}

\section{$2 \cdot 1$ 実戨用模型ビレット材料}

プラステシンは英国 Harbutt's plasticine 社製の一種 の油粘土で，主成分は方解石粉末 $\left(\mathrm{CaCO}_{3}\right)$ と鉱物油で ある。 その応力一丕関倸は GREEN ${ }^{14)}$ や粟野1516) らによ り，鋼の熱間加工温度領域におけるそれと類似し，普通 の機械仕上げ面の鋼製工具で $\mathrm{CaCO}_{3}$ または $\mathrm{CaSO}_{4}$ 粉 末を潤滑剂として用いる時，摩擦係数は $0.2 \sim 0.4$ とな
り鋼の熱間加工時の模型実験として用いることができる ことが明らかにされている、なお，プラステシンの塑性 はかなり温度に依存するので实験中室温は $20^{\circ} \mathrm{C} \pm 2^{\circ} \mathrm{C}$ の範囲内に維持した。

\section{$2 \cdot 2$ 装置および模型ビレット}

本実験において用いた孔型とビレットの寸法形状を Fig. 1 に示した。このパスデザインは United Steel 社 出版の Roll Pass Design ${ }^{17}$ )参考にして予備実験によ りビレットの孔型への充填が完全になるように定めた.

ロールは直径 $600 \mathrm{~mm}$ の鋼板製ロールにこれらの孔 型を刻んだ石高製の外径 $677 \mathrm{~mm}$ の円弧状ロールブロッ ク（ロールの一部分のみ）を取付けたものである。石高 型は十分乾燥させた後 1000 番のエメリ一紙で仕上げた. 模型ビレットは厚さ $4.0 \mathrm{~mm}$ の白色および灰色（白+10 \%黑) のプラステシン板を压延方向に垂直または平行に 交互に圧着しつつ積み重ねたものである.

\section{3 実験方法}

実験に際しては石膏ロールおよびビレットに $\mathrm{CaCO}$ 粉末を塗付し，ビレットが孔型に対し対称的に咬み込む ようガイドしつつ低速度で压延し，変形がほぼ定常状態 になつたと思われる位置で中止し，ただちにロールを逆 転してビレットを取り出した。圧延されたビレットのロ 一ル間腺下に当たる部分をロール軸に垂直な平面で数力 所細いピアノ線を用いて切断し,その面内のflow-pattern

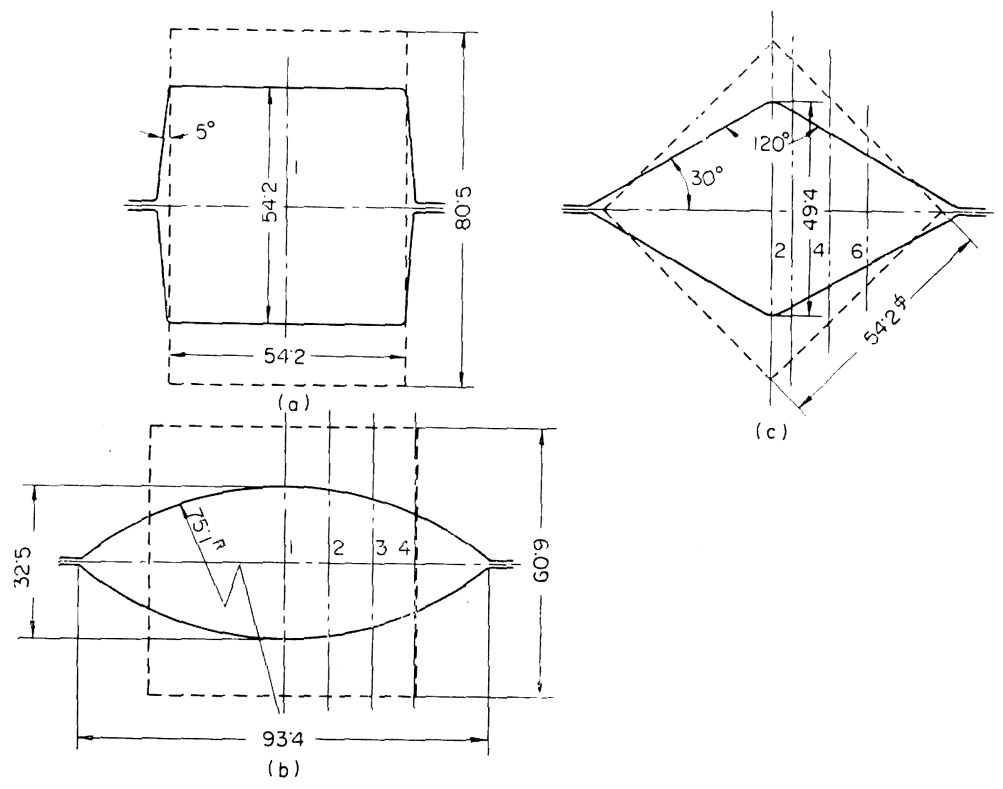

Fig. 1. The shape and dimension of roll-passes and billets: (a) box pass, (b) square-oval pass, (c) square-dia. pass. 


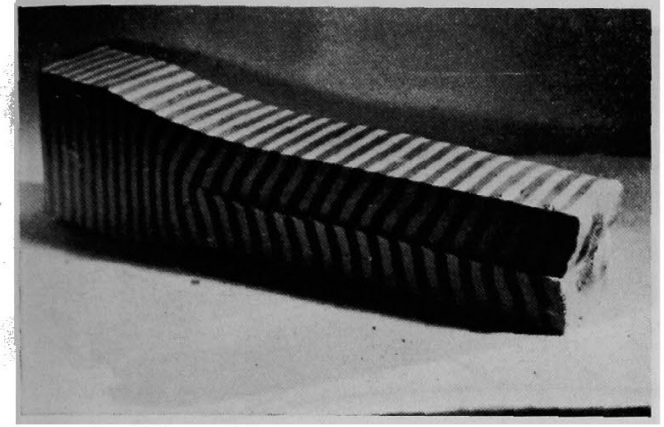

Photo. 1. Billet with transverse-vertical lamella after box-rolling.

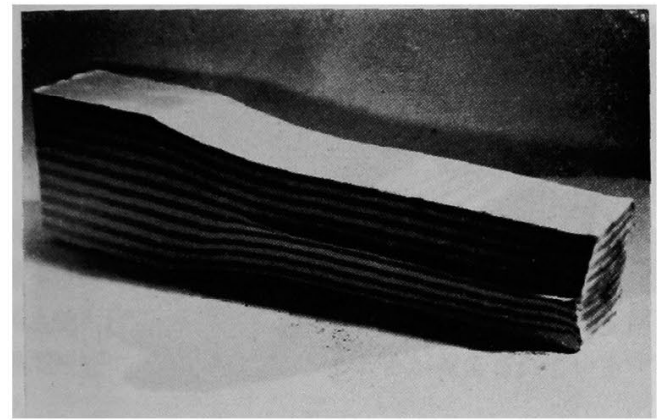

Photo. 2. Billet with horizontal-longitudinal lamesla after box-rolling.

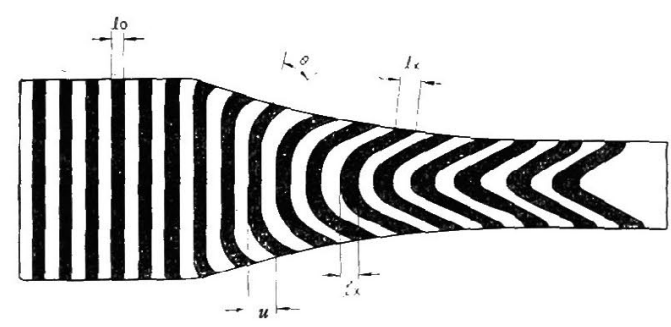

Fig. 2. Sketch illustrating analysis of flow-pattern: $u$ : deflection of vertical line; $\varepsilon_{x}=l_{x} / l-1$ : elongation strain; $\theta$ : shear angle on the contact surface.

を写真に撮り解析した。

\section{3. 実験結果および検討}

\subsection{How-pattern の解析法}

Fig. 2 は flow-pattern の解析法を示したもので，(1) 圧延方向に垂直な縞の彎曲量 $u$, (2)ビレットの表面およ び中心軸上での縞の間隔の变化率（圧延方向の伸び歪み $\left.\varepsilon_{x}=l_{x} / l_{0}-1\right)$, (3)ビレット表面上での縞の方向とロール 表面の法線のなす角度 $\theta$ (剪断角度) などを測定した。

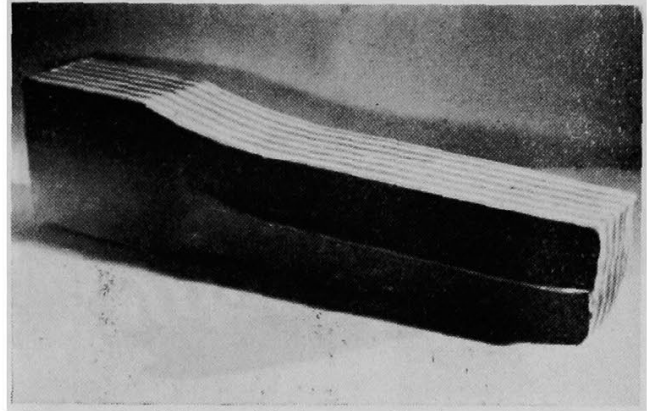

Photo. 3. Billet with longitudinal-vertical lamella after box-rolling.

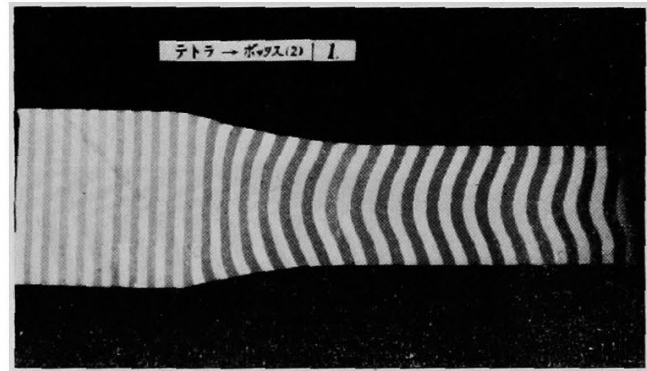

Photo. 4. Flow-pattern in the longitudinal-vertical plane of symmetry (refer to Photo.1).

\section{2 box 圧延}

box 压延はビレットの幅方向いずれの部分も圧下量が 同じなので投影接触面は $\square$ 形になつている. Photo. 1〜 3 は压延後の各種ビレットの外観である。やや過充㙵に なつている. Photo. 4 は Photo. 1 の中央断面における flow-pattern である.これを解析した結果を Fig. 3 に まとめて示した。

まず，縞の彎曲量 u（曲線 1 ）は咬込みと同時に生じ てほぼ面線的に增加し，接触弧の約 $2 / 3$ 進えだ位置で最 大となり以後出口に進皇につれて減少している。すなわ ち出口側で若干曲げ戻されて出ていく，ビレット表面の 壬延方向の伸び歪み $\varepsilon_{x}$ (曲線 2 ) 洨込みの少し手前 から生じ始め，接触弧の1/5の問に最終伸びの約70\%に 到達し, 接触弧の大部分の位置でそのまま变化せず出口 近くでいつたんやや減少した後残りの約 30\% の伸び変 形を起こして出ていく，ここでビレット表面の伸びが停 滞する範囲は明らかに固着 (adhesion) 領域である。こ れに対してビレットの水平中心面ては（曲線3）咬込み 点付近でまずいつたんやや縮えだ後, 表面より䄪 $20 \mathrm{~mm}$

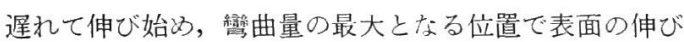
正みに追いついた後引続き上昇して出口より少し手前で 最終值に達する：この表面と中心面上の伸び歪みの一致 する点淜らかにロール周速と材料の中心部の速度が一 


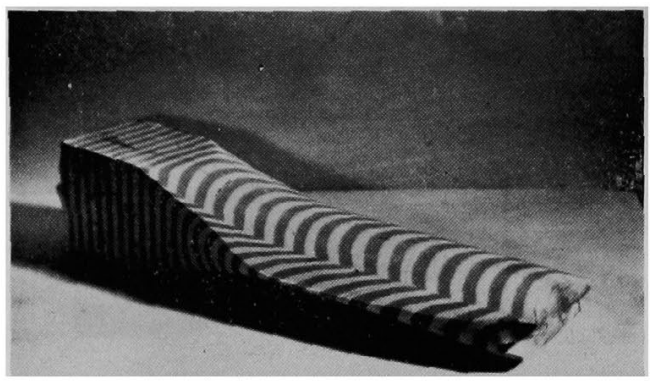

Photo. 5. Billet with transverse-vertical lamella after square-oval rolling.

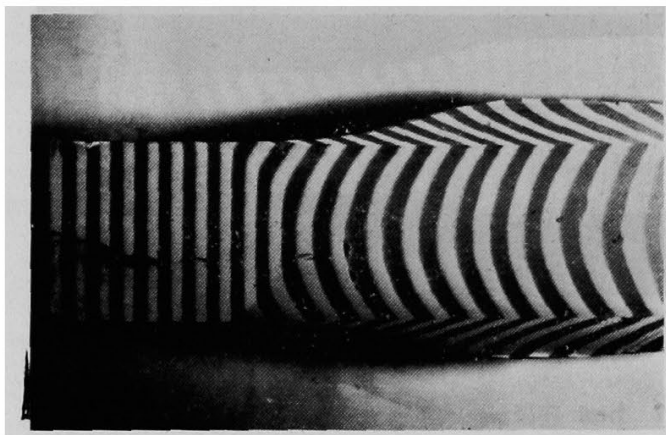

Photo. 6. The same billet as photo. 5. (view along normal direction of horizontal plane)

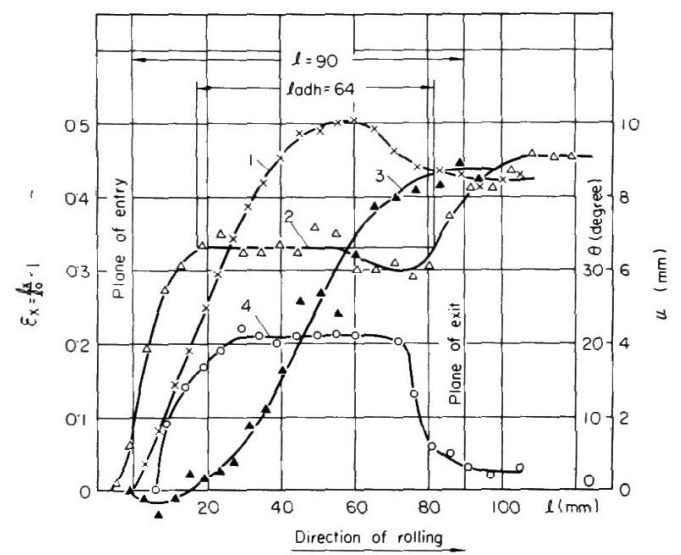

Fig. 3. Comparative graph of increasing deflection of vertical line $u(1)$, elongation strain $\varepsilon_{x}$ for elementary layers located on the contact surface (2) and in the horizontal plane of symmetry (3) and shear angle $\theta$ (4) all along the center of the width of the stock in the box pass.

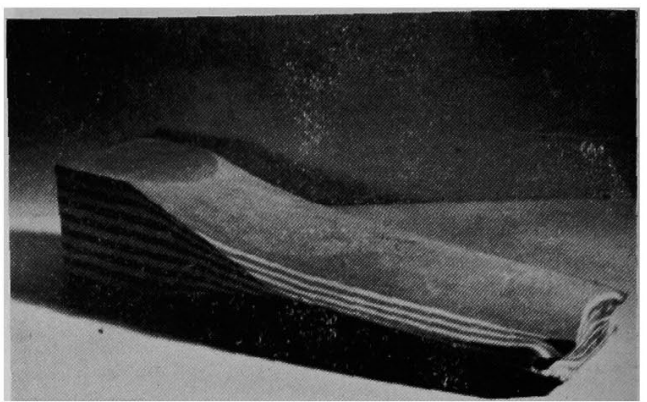

Photo. 7. Billet with horizontal-longitudinal lamella after square-oval rolling.

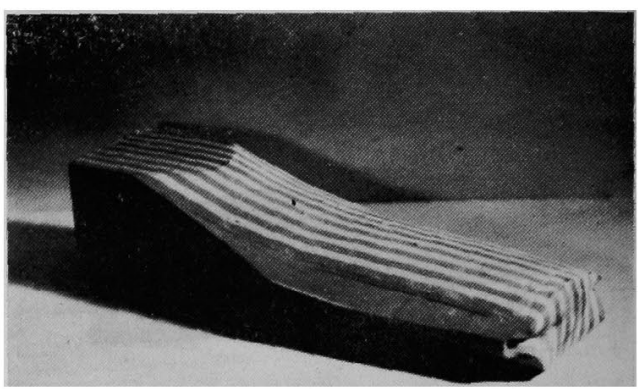

Photo. 8. Billet with longitudinal-vertical lamella after square-oval rolling.
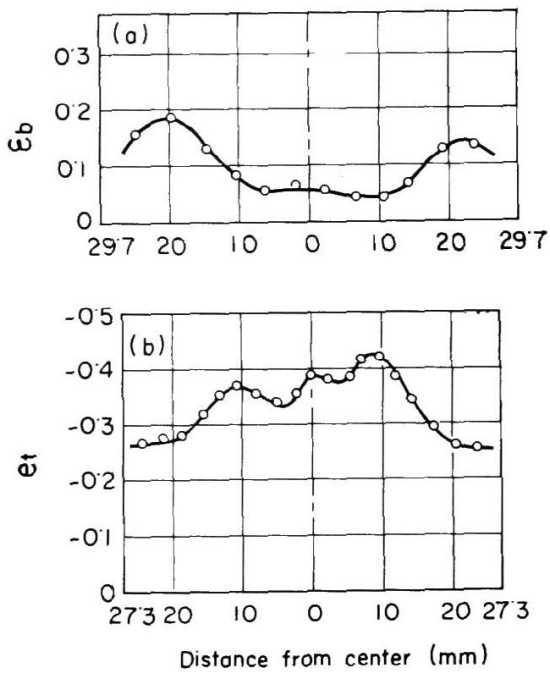

Fig. 4. The distributions of normal strain in the direction of spread $\varepsilon_{\mathrm{b}}$ along the horizontal axis of symmetry (a) and that in the direction of reduction $\varepsilon_{\mathrm{t}}$ along the vertical axis of symmetry (b) in the transverse-vertical cross-section of billet after box rolling. 


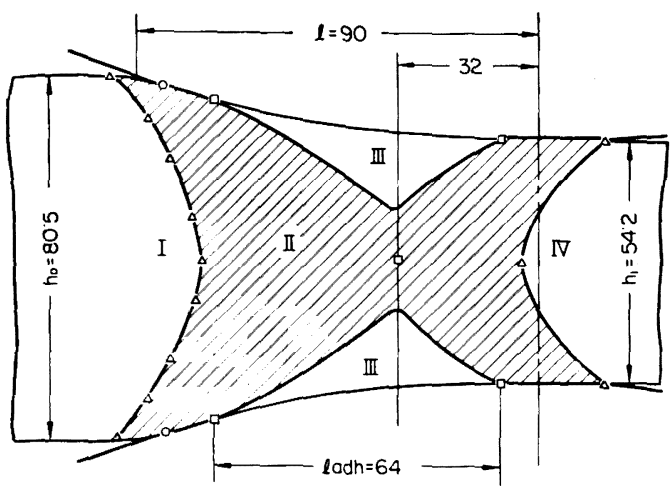

Fig. 5. Diagram of the deformation for box pass: I \& IV : non plastic zone toward entry and exit side (elastic wedge), II : zone of plastic deformation with extension in the longitudinal direction, II: zones of restricted deformation.

致した点, 寸なわち中立点である.したがつて縞の彎曲 量もほぼ中立点で最大になることがわかる、ここで中心 軸上伸び歪みが入口付近で負になることは実際の金属の 熱間圧延においても存在することが報告されている1)2)3) 5).

次に剪断角度 $\theta$ は咬込み点よりやや遅れて生じ急激に 上昇し, 接触弧の固着領域に相当する範囲でほほ一定值 を維持し，出口付近で急激に減少している.

Fig. 4 には圧延後のビレット横断面の水平対称軸上で の幅方向の公称歪 $\varepsilon_{b}$ および鉛直対称軸上の圧下方向の 公称歪 $\varepsilon_{t}$ の分布を示した. 全体的にほぼ均一な分布で あるが， $\varepsilon_{b}$ は端部近くで急に大きくなつている， $\varepsilon_{t}$ は 中央部で大きく，ロールに接する部分では小さくなつて いる.

Fig. 5 は以上の解析結果より接触弧内での変形領域を 推定した図である.四の斜線の部分は伸び歪みの上昇す る領域すなわち塑性変形領域である.この結果は I. Y $a$. TARNOVSKII らの研究結果5)上よく似ている。

\section{3 角一オーパル压延}

角一オーバル瓜延はビレットの中央部より側端部に近 い程死下量が大きいので，接触孤の長さは端部に近いほ ど長い.したがつて投影接触面の形状は凹形になつてい る.

Photo. 5〜8 は各種の縞を持つピレットの圧延後の外 観である. 入口側の咬込み線が压延方向（以後前方と呼 ぶ）に繇曲しているのは凹型接触面であることを示して いる. Photo. 5〜6 より质延方向に垂直の縞は压延方向 と逆の方向 (以後後方と呼ぶ) に彎曲していること, 口 ールと直接接触するピレットの上下の表面は圧延後もほ

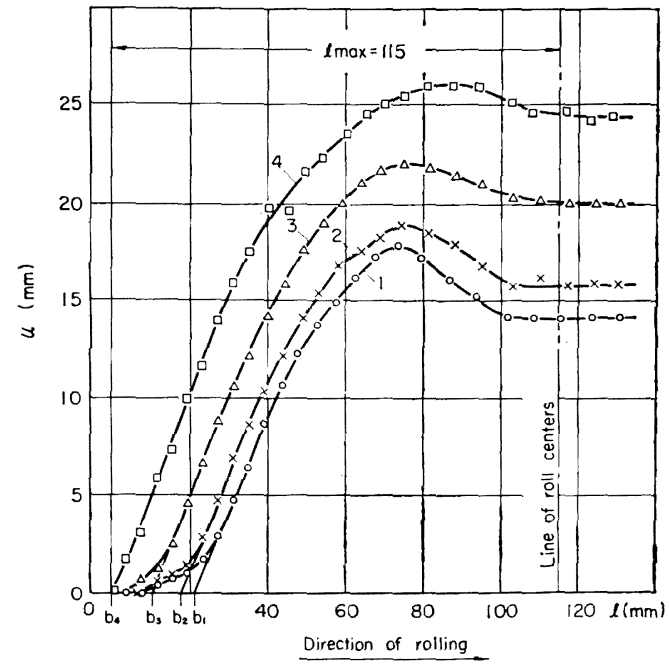

Fig. 6. Curves of the increasing deflection of vertical line $u$ in the longitudinal-vertical cross-sections for square-oval pass:

$1:$ in the center of the width; $2:$ at $10 \mathrm{~mm}$ from center; $3:$ at $20 \mathrm{~mm}$ from center; $4:$ at $30 \mathrm{~mm}$ from center and close to the edge of the width of the stock (refer to Fig. 1-b); $b_{1}, b_{2}, b_{3}, b_{4}$ : entry-point in each crosssection.

とんど幅拡がりを起こさず，幅拡がりは側面の膨れ出し によつて起こり，その側面が倒れてロール表面に接する ようになること, そのため側面の縞模様がロール表面に 現われて圧延前の角材の菱線が任延後も模様の不連続線 として残ること, ビレットの上下面の縞模様が晈込み線 を境に不連続的にぼけていることなどの特徵が明りよう である。

Photo. 9〜12 はロール軸に垂直な 4 個の面 (Fig. 1 の面 1 4) の flow-pattern である. Photo.13〜14 は 圧延後のビレットの横断面の flow-pattern である.

Fig. 6 は各面内の彎曲量 $u$ の変化するようすを示す. いずれも Fig. 1 の box 圧延の場合と類似の経過をた どつて接触弧の真中より出口側に最大点を有する.ここ で剩曲量は圧下量の大きいビレット側端に近いほど大き いこと, 最大点は側端に近いほど出口側に移行している こと, ビレット中央では咬込みのかなり前から等曲が始 まつていることなどの特徴が明らかである。

Fig. 7 はビレット表面および水平中心面での圧延方向 伸び歪み $\varepsilon_{x}$ を各断面について測定した結果である.や はり Fig. 1 の box 圧延の場合と類似の経過をたどる けれども，ビレット表面ではすべての断面で第一段階の 伸び歪みが最終歪の約 70\% であること, 入口側では接 触面の形状にしたがつて伸びの始まる位置がずれている 
が出口側の第 2 段階の伸びはほとえど同時に起こつてい ることなどの特徵がある、また，ビレット中心部の伸び 昰みは咬込み点直下付近でいつたん圧縮された後各断面 でほとえど同時に伸び出し，側端に近いところでは途中 小さな段を経て, 出口の手前で伸びは最大となり出口付 近で压縮されている。これらの曲線の交点から求めた 中立点はやはり Fig. 6 の彎曲量の最大点とだいたい一 致している.

Fig. 8 湔断角度で，ビレットの中央より側端に近い ほど大きく，圧延後の荊断角度は中央では負值になり， 側端に近いところでは正值になつている。また Fig.7 より求められる固着領域と剪断角度がほぼ一定になる範 囲注扮扮む权一致している。

Fig. 9 は压延後のビレット横断面（Photo.13〜14）の 水平対称軸にそつての幅方向歪 $\varepsilon_{b}$ と鉛直対称軸にそつ ての压下方向歪 $\varepsilon_{t}$ の分布である. $\varepsilon_{b}$ が著しく不均一分 布を示し，側端の䄳が非常に大きくなつている。これは 側端では圧下率が最も大きい上，ロールに拘束されない 自由表面が広いだ端面近くの材料の幅方向への流れが 特に大きいことによるものである。 $\varepsilon_{t}$ の分布は口ール表 面に接するところは摩擦のため幅方向に流れにくいのに 対し，中心部の流れが容易であることを示している.
Fig. 10は以上の解析結果より求めた角一オーバル任延 に対するロール間隙内での変形構造を示している. 図中 の曲線はすべて空間的な位置に存在するけれども，それ らを压延面（水平面）に投影したものである. ビレット は図の左から右へ流机，凹形の $\mathrm{b}$ 曲線より咬込まれ る.ビレット表面は咬込み前の $\mathrm{a}$ の位置から伸び变形を 開始するので，a はビレット表面の弾塑性境界である. c は前断危度の生ずる位置で，ビレットはこの位置から ロールと完全に接触していることを示している。d レットの水平中心面に㧍ける伸び正みの始まる位置で, これより手前で若干圧縮された後この位置より伸び出し ている.したがつて a-d 間の距㜠は表面と中心との伸 びの開始のずれを示し，弾性楔に相当する．ビレット中 央の接触面の凹部は側端の凸部によつて特にビレット内 部の伸び变形開始が早められていることがよくわかる. その結果凹部の弾性楔の長さが端の凸部のそれよりかな り短縮されている.こ㞦は接触面の凸部と凹部の相互作 用が相当に著しいことを暗示している。すなわち凸部は 凹部によつて変形を拘束され，凹部は凸部によつて促進 されていることを示している．f は中立線であり，生延 方向の伸び歪みより求めた点（黑丸）と䅬曲量曲線より 求めた点（白角）とが打おむ致一致しており，側端飞近

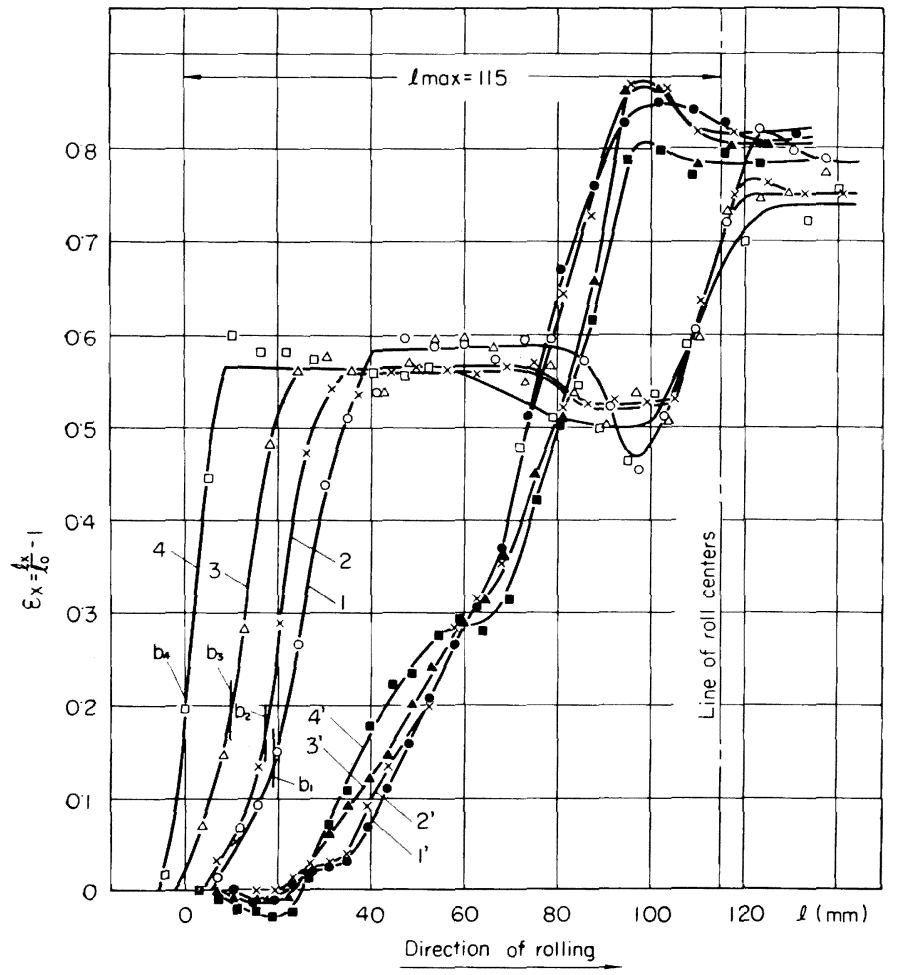

Fig. 7. Curves of the increasing elongation strain $\varepsilon_{x}$ for the elementary layers located on the contact surface (1-4) and in the horizontal plane of symmetry $\left(1^{\prime}-4^{\prime}\right)$ for square-oval pass:

$1 \& 1^{\prime}$ : in the center of the width; $2 \& 2^{\prime}$ : at $10 \mathrm{~mm}$ from center; $3 \& 3^{\prime}$ : at $20 \mathrm{~mm}$ from center; $4 \& 4^{\prime}$ : at $30 \mathrm{~mm}$ from center and close to the edge of the width of the stock. 

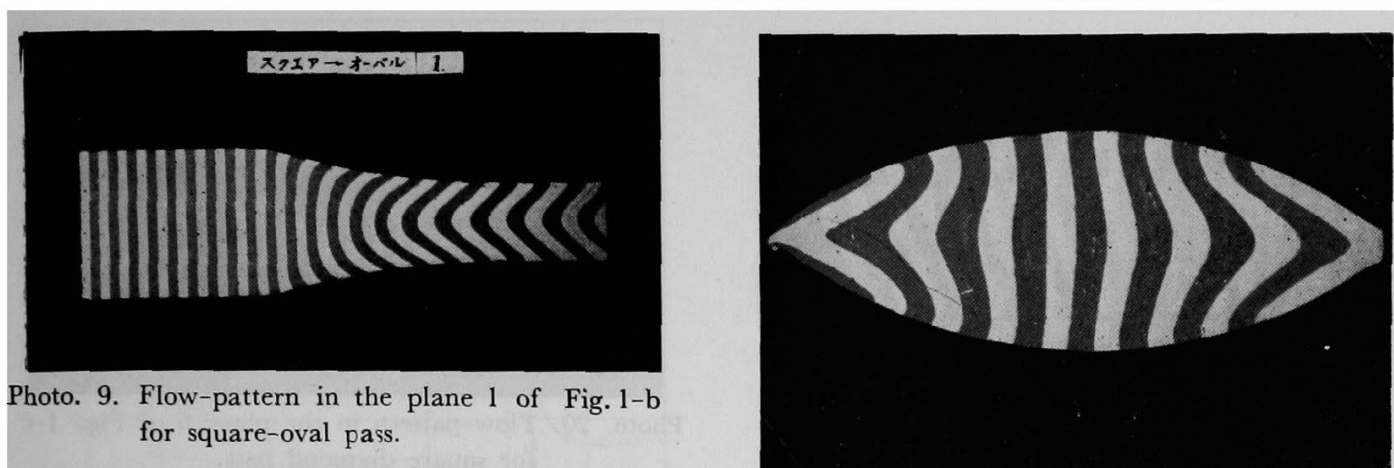

Photo. 9. Flow-pattern in the plane 1 of Fig. 1-b for square-oval pass.

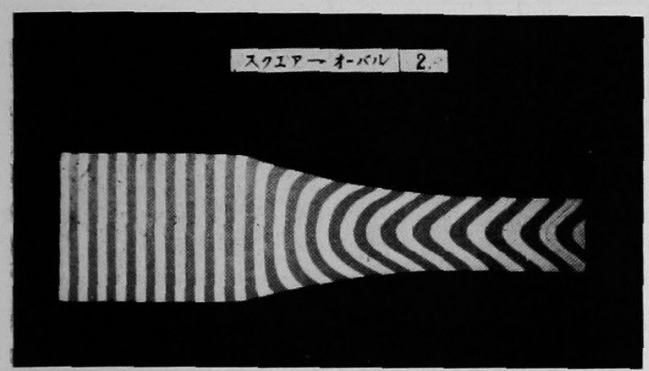

Photo. 13. Flow-pattern in the cross-section of billet after square-oval rolling. (refer to Photo. 8)

Photo. 10. Flow-pattern in the plane 2 of Fig. 1-b for square-oval pass.

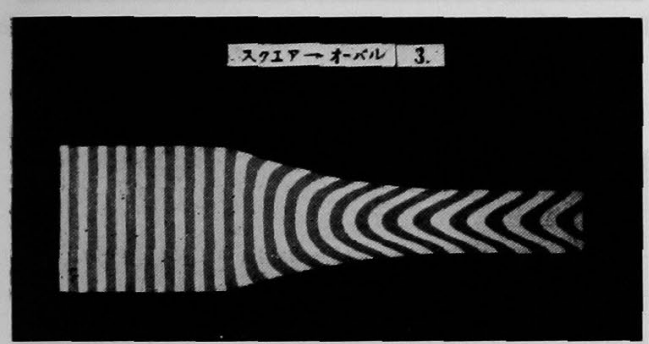

Photo. 11. Flow-pattern in the plane 3 of Fig. 1-b for square-oval pass.

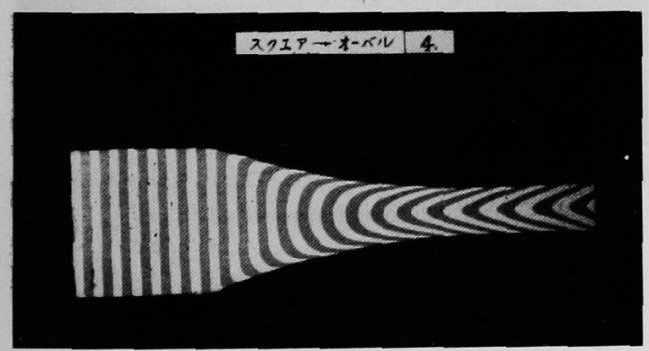

Photo. 12. Flow-pattern in the plane 4 of Fig. I-b for square-oval pass.

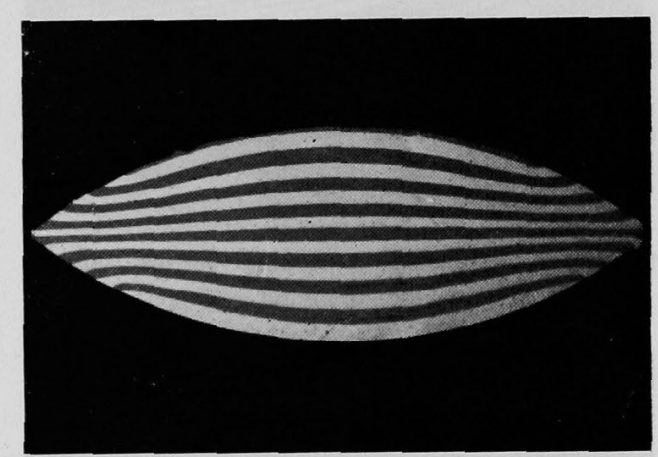

Photo. 14. Flow pattern in the cross-section of billet after square-oval rolling. (refer to Photo. 7)

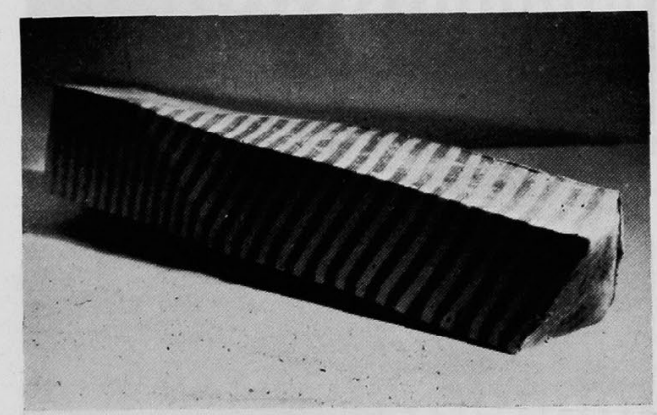

Photo. 15. Billet with transverse-vertical lamella after square-diamond rolling. 


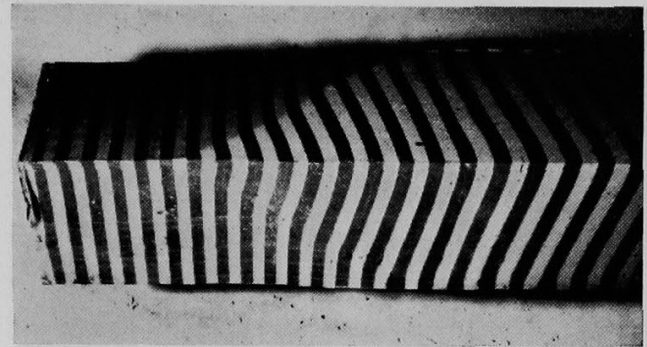

Photo. 16. The same billet as Photo. 15 (view along normal direction of horizontal plane).

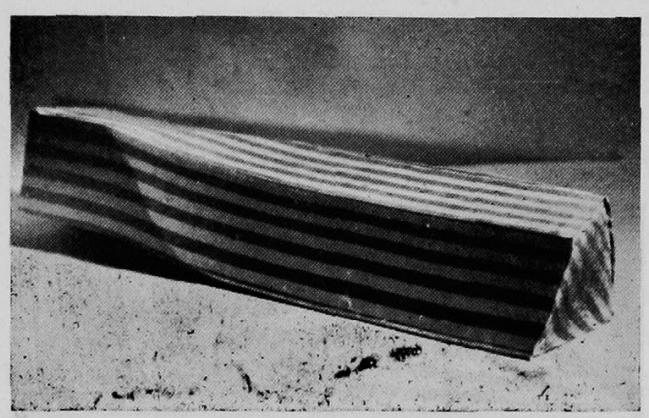

Photo. 17. Billet with longitudinal-vertical lamella after square-diamond rolling.

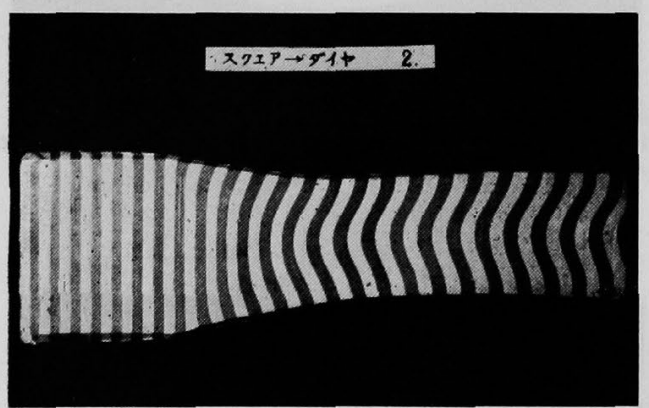

Photo. 18. Flow-pattern in the plane 2 of Fig. 1-c for square-diamond pas:

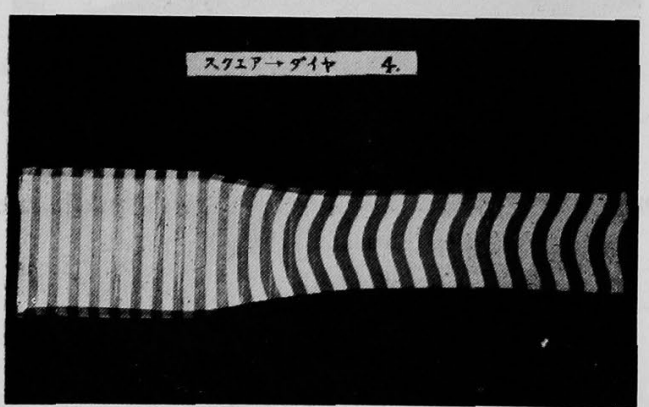

Photo. 19. Flow-pattern in the plane 4 of Fig. 1-c for square-diamond pass.

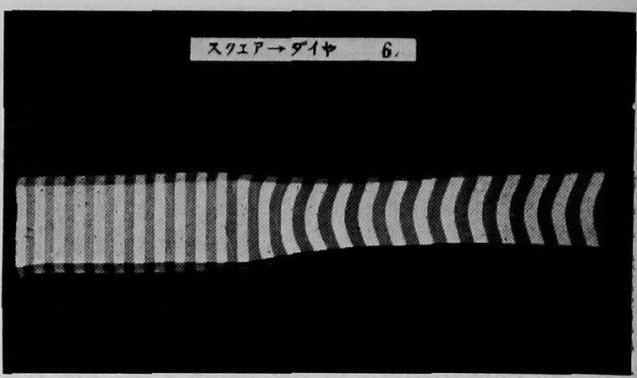

Photo. 20. Flow-pattern in the plane 6 of Fig. 1-c for square-diamond pass.

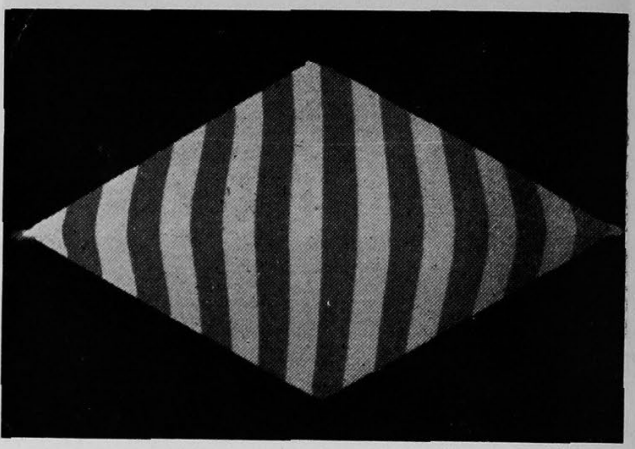

Photo. 21. Flow-pattern in the cross section of billet after square-diamond rolling. (refer to Photo. 17)

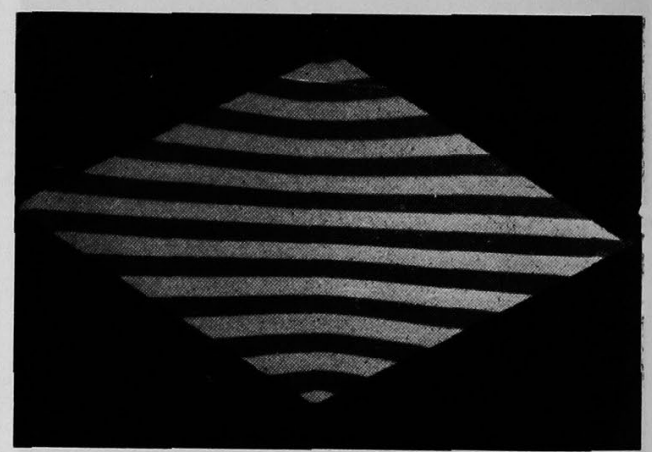

Photo. 22. Flow-pattern in the cross-section of billet after square-diamond rolling. 


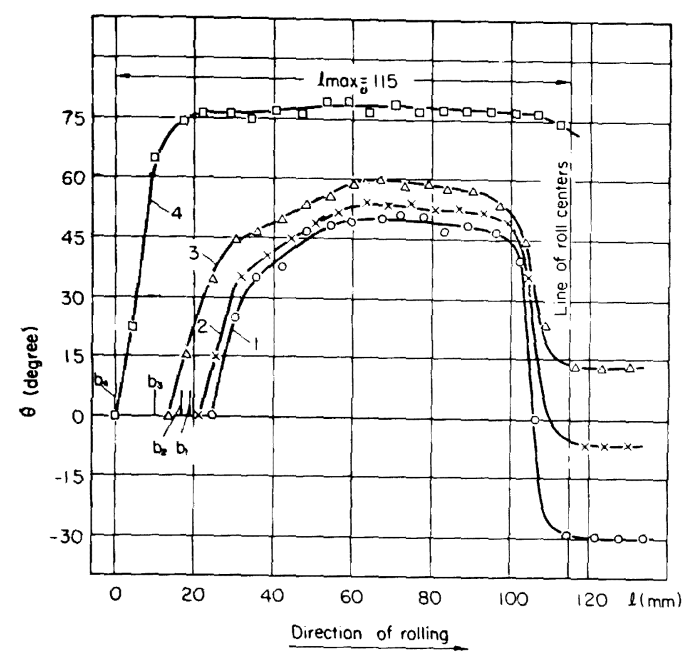

Fig. 8. Variation of shear angle $\theta$ along the arc of contact in each longitudinal-vertical plane for square-oval pass:

1,2,3,4: traverse location (refer to Fig. 6 or 7 ).

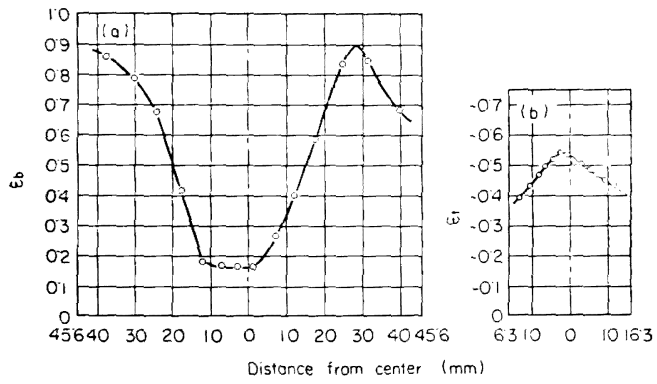

Fig. 9. The distributions of normal strain in the direction of spread $\varepsilon_{\mathrm{b}}$ along the horizontal axis of symmetry (a) and that in the direction of reduction $\varepsilon_{t}$ along the vertical axis of symmetry (b) in the transversevertical cross-section of billet after squareoval rolling.

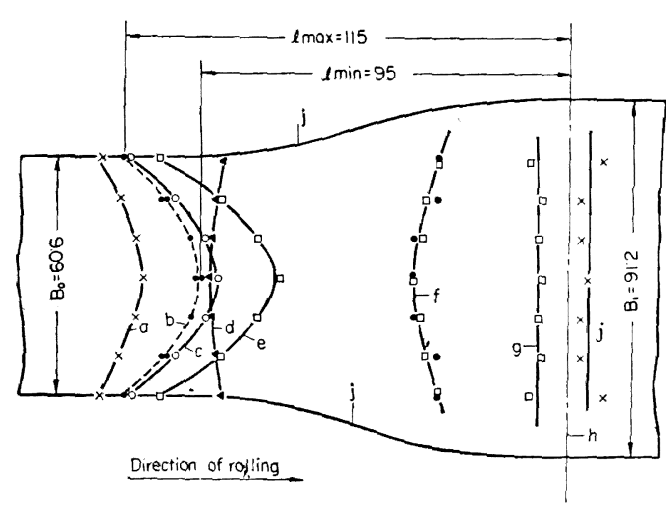

Fig. 10. Diagram of the deformation for squareoval pass (view along normal direction of horizontal plane): a \& i : elasto-plastic boundary on the surface of the stock; $b$ : boundary of contact surface; $c$ : boundary across which shear strain arises on the contact surface; $d$ : elasto-plastic boundary in the horizontal plane of symmetry; e $\& \mathrm{~g}$ : limiting lines between which adhesion occurs; $f$ : neutral line; $h$ : line of roll centers; $\mathrm{j}$ : contour of the stock.

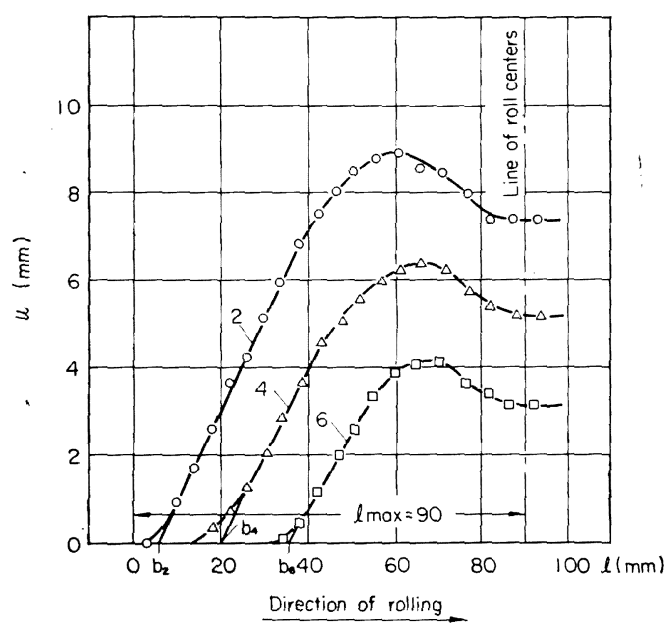

Fig. 11. Curves of the increasing deflection of vertical line $u$ in the longitudinal-vertical crosssections for square-dia. pass:

$2:$ at $4.5 \mathrm{~mm}$ from center of the width; 4 : at $13 \mathrm{~mm}$ from center; $6:$ at $21.5 \mathrm{~mm}$ from center (refer to Fig. 1-c); $b_{2}, b_{4}, b_{6}$, : entry point in each cross-section 
いところほど出口側に近づいている。これはロール周速 が側端に近いはど大きいことが主な原因と考えられる。 $\mathrm{e}$ と $\mathrm{g}$ によつて挾まれる領域は固着領域である。 i は口 一ル表面の出口側の弾塑性境界である。 j はビレットの 水平中心面に抢ける輪郭線であり, 幅搪がりの大部分は dからfの間で起こつている.

\section{4 角一ダイヤ圧延}

角一ダイヤ压延は佮一オーバル压延と対照的にビレッ トの中央部の万が压下量が大きいので投影接触面の形状 は凸形になつている。

Photo. 15〜17 は各租の縞を持つビレットの压延後の 外観である.入口の咬込み線は领く後方に向かつて突出 している. Photo. 15〜16 より，压延前に压延方向に垂 直な縞は接触面上では角一オーバル压延と対照的に前方 に彎曲していること，巾拡がりが非常に少ないこと，全 体的に縞の变形が均一であることなどの特徵が明らかて ある・

Photo. 18〜20 は Fig. 1 の 2 点鎖線 2, 4, 6 に対 応する面内の flow-pattern である. すべて圧延に固有 の pattern を示している. Photo. 21〜22 は压延後のビ レットの横断面内の flow-pattern である.

Fig. 11 は各面内の綮曲量 $u$ の変化するようすを示 す.いずれも Fig. 1 の box 压延の場合と類似してい る.この場合鳘曲量は在下量の大きいビレット中央部に 近いほど大きいこと，角一オーバルの場合と同様に最大
点は側端に近いほど出口側に移行していることなどの特 徵が明らかである。しかし彎曲量は角一オーバルに比較 して非常に小さい.

Fig. 12 はビレット表面および水平中心面上の圧延方 向の伸び歪み $\varepsilon_{x}$ を各断面について測定した結果であ る. 表面ではすべての面について 2 段階に伸びが起こり 第1 段階の伸びは最終伸びの約 $70 \%$ になつていること はbox 压延, 角一オーバル压延と同様である. また, 表面では咬込み点の位置にしたがつて伸びの開始点もず れているが，中心部の伸びがほとえど同時に始まること も角一オーバルと類似している。

Fig. 13 は各断面の剪断角度を示しているが, 角一オ 一バルの場合より非常に小さい. しかし Fig.11 の結曲 量とは逆に端に近いはど大きいのはやはりロール周速が 端に近いほど大きいことと対応していると考えられる。 なお，剪断角度がだいたい一定の領域は Fig. 12 の伸び 歪灭により求められる固着領域とほぼ一致している.

Fig. 14 は框延後のビレットの横断面内の幅方向歪 $\varepsilon_{b}$. 生下方向歪 $\varepsilon_{t}$ の対称軸上の分布である. 諙一オーパル の場合と異なつて幅方向歪 $\varepsilon_{b}$ はビレットの中心と両端 に低い山を持っ比較的均一な分布を示している. 中心の 山はここで压下率が大きい為に現われたものであり，端 部は自由表面部の幅拡がりによるものである. $\varepsilon_{t}$ の分 布は角一オーバルの場台と類似している.

Fig. 15 は以上の解析結果より求めた角一ダイヤ圧延

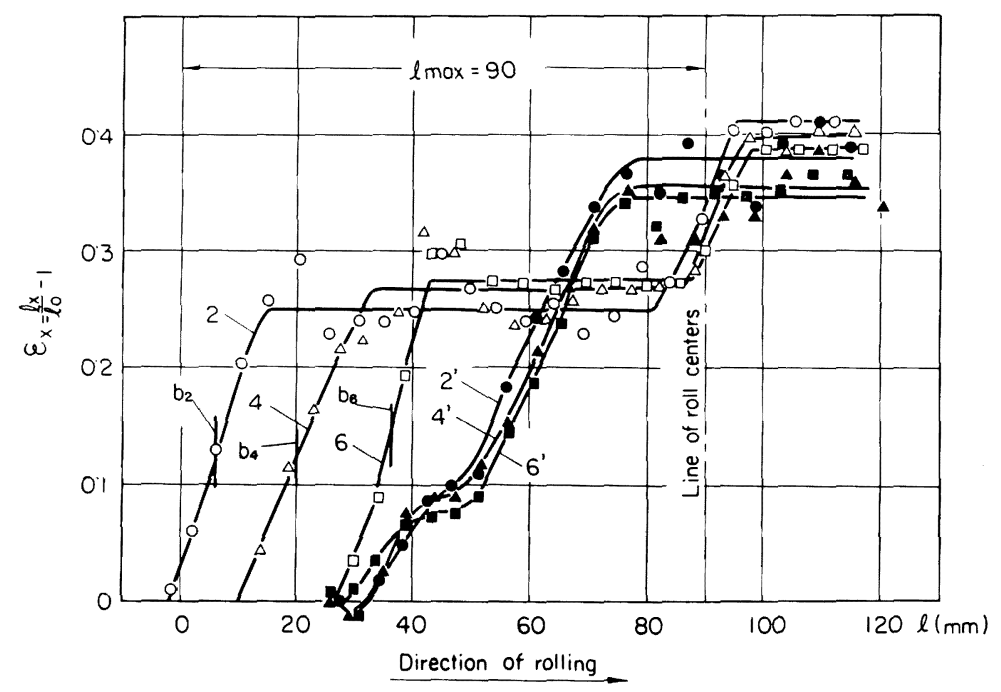

Fig. 12. Curves of the increasing elongation strain $\varepsilon_{x}$ for the elementary layers located on the contact surface (2-6) and in the horizontal plane of symmetry $\left(2^{\prime}-6^{\prime}\right)$ for square-dia. pass: $2 \& 2^{\prime}:$ at $4 \cdot 5 \mathrm{~mm}$ from center of the width; $4 \& 4^{\prime}$ : at $13 \mathrm{~mm}$ from center; $6 \& 6^{\prime}$ : at $21 \cdot 5 \mathrm{~mm}$ from center. 


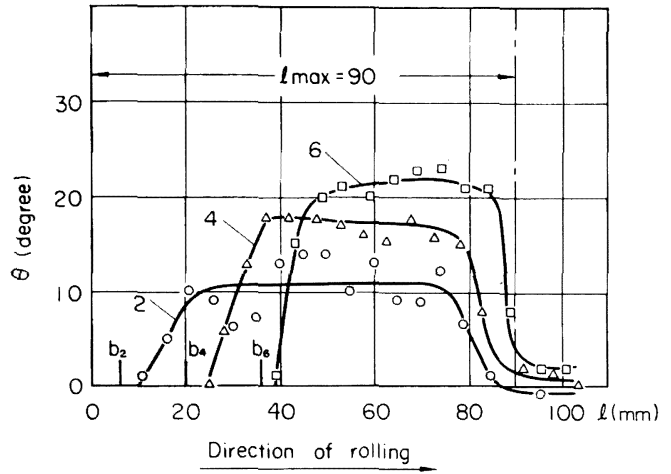

Fig. 13. Variation of shear angle $\theta$ along the arc of contact in each longitudinal-vertical plane for square-dia. pass:

2, 4,6: traverse location (refer to Fig. 11 or 12).

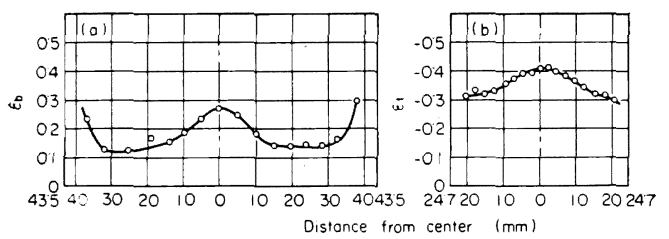

Fig. 14. The distributions of normal strain in the direction of spread $\varepsilon_{\mathrm{b}}$ along the horizontal axis of symmetry (a) and that in the direction of reduction $\varepsilon_{\mathrm{t}}$ along the vertical axis of symmetry (b) in the transversevertical cross-section of billet after squaredia. rolling.

に対するロール間陌内での変形構造である。ロール表面 の伸び開始線 $\mathrm{a}$ および水平中心面での伸び開始線 $\mathrm{d} の$ 形 状より，ビレット中央の接触面の凸部の变形によつて側 端に近いところの塑性変形が著しく促進されていること がわかる．したがつて凸部の变形はとの両側の弾性材料 によつて著しく拘束されていることが想像できる，fの 中立線の形状が側端に近いはど出口側に寄つているのは 角一オーバル圧延と類似しており，ロール周速が端に近 いほど速いことによると考えられる。 jの巾拡がりはや はり aからfの間でほとんど起こつている。

\section{4. 総括}

ブラステシンを用いて鋼材の熱間孔型王延の模型実験 を行ない，孔型圧延の中で接触面の形状によつて分類し た凹形接触面を持つ角一オーバル圧延，凸形接触面を持 つ角一ダィヤ圧延および両者の中間的な $\square$ 形接触面を持

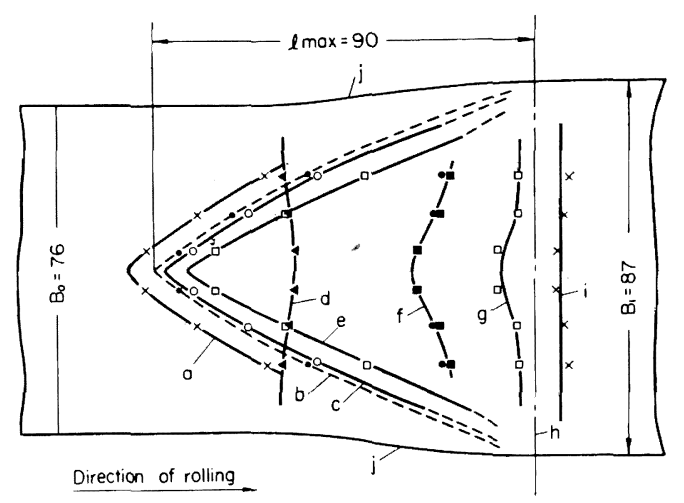

Fig. 15. Diagram of the deformation for square-dia. pass (view along normal direction of horizontal plane): a \& i : elasto-plastic boundary on the surface of the stock; b : boundary of contact surface; c : boundary across which shear strain arises on the contact surface; d : elasto-plastic boundary in the horizontal plane of symmetry; e \& $g$ : limiting lines between which adhesion occurs; $f$ : neutral line; $h$ : line of roll centers; $j:$ contour of the stock.

つbox 压延について，ロール間隙内における材料の变 形過程を明らかにした，その結果を要約すると次のとお りである。

（1）压延方向に垂直な縞のビレット表面における変 形は接触面の形状によつて著しく異なり，凹形接触面の 角一オーバル压延では压延方向上逆の方向に簿曲し，か つ圧延前のビレット側面が幅拡がりによつて膨狆出し， 表面に現わ机るため複雑な形になる. そ机に対し角一夕゙ イヤ压延では压延方向に䋨曲するが，全体的に均一な变 形である。box 压延では就曲は起こらない。

（2）接触面に凹凹がある場合，凹形接触面の凹部や 凸形接触面の端に近いこころ，寸なわち遅れて变形を受 ける部分は凸部寸なわち早く変形さ机る部分との相互作 用によつて変形が促進され，特にビレット内部の弾塑性 境界が後方に移動し, したがつて弾性楔の長さが短縮さ れる。この効果法逆に凸部の変形がその粼接する凹部の 弾性部分により拘束されていることを示している。した がつてこの相互作用は凸形接触面では特に著しいと考え られる。

（3）中立点法ビレットの表面と水平中心面での压延 方向の伸ひ歪みの等しい位置から求めら机たが，この位 置は圧延方向に垂直の縞の彎曲量が最大となる位置と常 によく一致していた。このようにして求めた中立線の形 
状は，接触面とは無関係に压延方向と逆の方向に彎曲し ていた．これは中立線の形は主としてロール周速の巾方 向の分布によつて决まることを暗示している.

（4）熱間圧延では接触面のいかんにかかわらず，接 触面のうち入口および出口付近の狭い帯状の部分以外で は固着が起こつている.

（5）幅拡がりは入口側でビレットの水平中心面が塑 性変形を始める位置から中立線までの領域でほとえど起 こる.

（6）圧延後のビレット横断面内の幅方向の歪分布は 凸形接触面を持つ压延では比較的均一であるが，凹形接 触面を持つ压延の場合, 端部の幅拡がりによつて端部で 非常に大きくなり不均一分布になる.

本研究の遂行に当たつてビレットの作製および圧延作 業の大部分を担当された千野達吉氏に謝意を表する。

\section{交献}

1) N. Metz: Arch. Eisenhüttenw., (1927)

2 ) S. Ekelend: Steel, 93 (1933)

3 ) L. Weiss: Z. Metallkunde, 20 (1928)

4 ) E. Orowan: Proc. I. Mech. E., 150 (1943), 4

5 ) I. Ya. Tarnovskil, $A . A$. Pozdeyev and $V . B$.
Lyashkov: Deformation of Metals during Rolling, (First English Edition 1965), [Pergamon Press]

6 ) C. W. MacGregor and L. F. Coffin, Jr.: J. of Appl. Mech., (1943), March

7 ) $H$. Meyer and F. Nehl: Stahl u. Eisen, 45 (1925)

8 ) E. Cotel: Úber die Begleiterscheinung des Walzuorganges, (1924) 636, [Montan Rdsch.]

9 ) B. B. Hundy: J. Iron \& Steel Inst. (U.K.)

10) C. W. MagGregor: T. P. No. 1036, Metals Technology, (1938) April

11) J. M. Capus and $M . G$. Cockcroft: J. Inst. Metals, 90 (1961-62)

12) 五弓勇雄, 颸藤好弘: 日本金属学会誌, 29 (1965) 10

13）柳本左門：塑性と加工， 2 (1961) 9

14) A. P. Green: Phil. Mag., 42 (1951) 327, April

15）粟野泰吉, 落合正男: 名古屋工業技術試験所報告 6-1 (1957)

16）栗野泰吉：塑性と加工，１（1960)，3

17) United Steel Co. Ltd.: Roll Pass Design, (1960), Percy Lund. Humpheries \& Co. Ltd. 